\title{
Perception and Knowledge Regarding Role of Physiotherapy in Oral/Mouth Cancer Survivors amongst Non Medical Profession- als: An E-Survey
}

\section{Renu Pattanshetty ${ }^{* 1}$, Siddhi Gotecha ${ }^{2}$, Harshitha Hugar ${ }^{3}$.}

${ }^{* 1}$ Professor and Head, Department of Oncology Physiotherapy, KAHER Institute of Physiotherapy, Belagavi, Karnataka, India.

2,3 Intern, KAHER Institute of Physiotherapy, Belagavi, Karnataka, India.

\section{ABSTRACT}

Background \& Objectives: About 5 million people are diagnosed with cancer worldwide. $50 \%$ are expected to live at least 5 years with most survivors living with cancer related disabilities. Physiotherapy rehabilitation becomes crucial for better quality of life after cancer treatment. The objective of the present study was to assess the perception and knowledge regarding role of physiotherapy in oral/mouth cancer survivors amongst non medical professionals in India.

Methodology: This e-survey was conducted using a self -prepared questionnaire in English language carried out for a period of 3 months. Questionnaire was circulated among respondents across India via social media

Results: Out of 265 respondents, a total of $92.8 \%$ respondents had fair knowledge regarding oral cancer and its causes. $57.7 \%$ respondents had knowledge about problems faced by oral cancer survivors. Physiotherapy as a treatment option was known to $87.9 \% .75 \%$ respondents possessed knowledge of physiotherapy in treating functional limitations seen in oral cancer patients.

Conclusion: There was sufficient knowledge among the respondents regarding oral cancer and physiotherapy treatment in oral cancer survivors. However, there is a dire need to take measures to assess the awareness of physiotherapy in cancer to improve quality of life amongst rural population.

KEY WORDS: Perception, Oral cancer survivors, Human papilloma virus (HPV), Palliative care, Physiotherapy, uality of life.

Address for correspondence: Dr. Renu Pattanshetty ${ }_{M P T, P h . D^{\prime}}$ Professor and Head, Department of Oncology Physiotherapy, KAHER Institute of Physiotherapy, Belagavi, Karnataka, India. Mob. No.: +919448482564 E-Mail: renu_kori@rediffmail.com

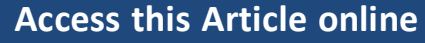

Quick Response code

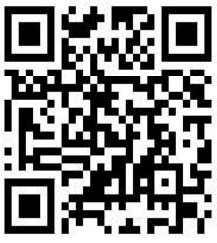

DOI: $10.16965 /$ ijpr.2021.122
Journal Information

International Journal of Physiotherapy and Research ISSN (E) 2321-1822 | ISSN (P) 2321-8975

https://www.ijmhr.org/ijpr.html

DOI-Prefix: https://dx.doi.org/10.16965/ijpr

(cc) BT-Mo-si

Article Information

Received: 09 Mar 2021

Accepted: 10 May 2021

Peer Review: 09 Mar 2021

Published (O): 11 Jun 2021

Revised: None

\section{INTRODUCTION}

Cancer is a leading health problem in India, with approximately one million cases occurring each year. Over 200,000 cases of head and neck cancer occur each year in India [1]. The world's highest incidence of cancers associated with tobacco are found in districts of northeast, central and southern
India [2]. Oral cancer is one of the most fatal health problem faced by mankind today. In India, because of the cultural, ethnic, geographic factors and the popularity of addictive habits, the frequency of oral cancer is high. Several factors like tobacco and its related products, alcohol and genetic predisposition are suspects as 
possible causative factors [3]. Cancer and its various treatments can result in impairments, which can affect multiple body systems. These impairments restrict physical functioning and participation in activities of daily living and quality of life. Many such impairments are amenable to physiotherapy interventions [4].

Physiotherapy is one of the oldest professions in healthcare practice since 460 B.C by as documented by great physicians such as Hippocrates and Galen. Due to continuous efforts, research and development of various techniques over the years, it has gained recognition and appraisal with its evidence based practice. According to World Confederation of Physical therapy, "Physical therapy is concerned with identifying and maximizing quality of life movement potential within the sphere of promotion, prevention, treatment and rehabilitation. This encompasses physical, psychological, emotional, and social wellbeing. Recent studies shows that there is adequate knowledge of physiotherapy in musculoskeletal, sports, neuroscience. Some fields like physiotherapy in OBG, plastic surgery, oncology, cardiopulmonary are poorly known to non medical professionals [5]. There are numerous studies that have shown beneficial effects of physiotherapy interventions. However, the integration of physiotherapy services in cancer care continues to languish [4]. Hence, there is a need to assess the knowledge regarding physiotherapy in oral cancer amongst non-medical professionals in India.

\section{MATERIALS AND METHODOLOGY}

An ethical clearance was obtained from the Institutional Ethical Committee (REF/SL no.770, obtained on $6^{\text {th }}$ November 2020) prior to the commencement of the study. The study period ranged from October to December 2020 at KAHER Institute of Physiotherapy, Belagavi, Karnataka. The calculated sample size was two hundred and sixty four (264) based on the prevalence rate formula $\left(n=Z^{2} x p q / e^{2}\right)$ where $n=$ sample size, $Z$ =expected confidence level $p=$ prevalence level, $q=1-p, e=$ accuracy level.
The e-survey was a self designed questionnaire which included open and closed ended questions which was circulated using Google forms using WhatsApp, Facebook, and Email. An E-Informed consent was obtained prior to participation attached to the $1^{\text {st }}$ part of the Google questionnaire. The timing was tested prior to circulation that took total of 13 minutes to record the responses. All respondents across India of both gender who were willing to participate and were over the age of 22 years and above got included in the study. The questions were framed to inquire respondents knowledge under the following headings:

- Demographic Data/Profile

- Knowledge of Oral Cancer

- Knowledge of cause of Oral Cancer

- Knowledge of problems faced by Oral Cancer survivors

- Knowledge of treatment options for Oral Cancer

- Knowledge of role of physiotherapy in Oral Cancer

- Knowledge of psychosocial impact on Oral cancer survivors

The data was then tabulated and analyzed.

\section{RESULTS}

Most of the responses were from age group belonging to $22-29$ years $(n=193)$. The least response was from age group of 50 years and above $(n=13)$. Female respondents were dominant $(n=143)$ then followed by males $(n=121)$. Maximum respondents were from Maharashtra $(n=82)$ followed by Karnataka $(n=43)$ followed by Madhya Pradesh $(n=13)$, Gujarat $(n=8)$, Andhra Pradesh $(n=4)$, Rajasthan $(n=4)$, Goa $(n=4)$, Kerala $(n=4)$, Haryana $(n=3)$ respectively. Maximum number of respondents were Engineers by profession ( $n=85$ ) followed by Entrepreneurs $(n=39)$ and others. Most respondents did not report of any habits $(n=183)$ (Table 1$)$. Maximum respondents had knowledge regarding oral cancer $(n=246)$ including oral cancer being $2^{\text {nd }}$ highest cause of death $(n=145)$. 
Table 1: Demographic profile of all the participants in E-survey.

\begin{tabular}{|c|c|c|c|}
\hline Variables & Responses & $\begin{array}{l}\text { Frequency } \\
\text { (n) }\end{array}$ & $\begin{array}{l}\text { Percentage } \\
\%\end{array}$ \\
\hline \multirow{5}{*}{ 1.Age } & 22-29 years & 193 & 72.8 \\
\hline & 30-39 years & 24 & 9.1 \\
\hline & 40-49years & 35 & 13.2 \\
\hline & 50 years and above & 13 & 4.9 \\
\hline & Total & 265 & 100 \\
\hline \multirow{4}{*}{ 2.Gender } & Female & 143 & 54 \\
\hline & Male & 121 & 45.7 \\
\hline & Others & 1 & 0.4 \\
\hline & Total & 265 & 100 \\
\hline \multirow{10}{*}{ 3.State } & Karnataka & 143 & 54 \\
\hline & Maharashtra & 82 & 30.9 \\
\hline & Andhra Pradesh & 4 & 1.5 \\
\hline & Rajasthan & 4 & 1.5 \\
\hline & Haryana & 3 & 1.1 \\
\hline & Goa & 4 & 1.5 \\
\hline & Kerala & 4 & 1.5 \\
\hline & Gujarat & 8 & 3 \\
\hline & Madhya Pradesh & 13 & 4 \\
\hline & Total & 265 & 100 \\
\hline \multirow{8}{*}{ 4.Profession } & Engineer & 85 & 32.1 \\
\hline & Banker & 24 & 9.1 \\
\hline & Entrepreneur & 39 & 14.7 \\
\hline & Teacher & 21 & 7.9 \\
\hline & Lawyer & 9 & 3.4 \\
\hline & CA & 3 & 1.1 \\
\hline & Others & 84 & 31.7 \\
\hline & Total & 265 & 100 \\
\hline \multirow{5}{*}{ 5.Qualification } & Graduate & 183 & 69.1 \\
\hline & PostGraduate & 75 & 28.3 \\
\hline & PhD & 4 & 1.5 \\
\hline & Others & 3 & 1.1 \\
\hline & Total & 265 & 100 \\
\hline \multirow{5}{*}{ 6.Do you have any of the habits mentioned below? } & Consuming tobacco in any form & 18 & 6.4 \\
\hline & Alcohol consumption & 58 & 22.3 \\
\hline & Recreational Drugs & 6 & 2.3 \\
\hline & None & 183 & 69.1 \\
\hline & Total & 265 & 100 \\
\hline \multirow{6}{*}{$\begin{array}{l}\text { 7. If you are a smoker, how many cigarettes do you } \\
\text { smoke per day? }\end{array}$} & No response & 247 & 84.2 \\
\hline & $<10$ cigarettes per day & 11 & 13.2 \\
\hline & $>10$ cigarettes per day & 4 & 1.5 \\
\hline & $>20$ cigarettes per day & 2 & 0.8 \\
\hline & $>25$ cigarettes per day & 1 & 0.4 \\
\hline & Total & 265 & 100 \\
\hline \multirow{6}{*}{$\begin{array}{l}\text { 8. If you consume alcohol, on an average how much } \\
\text { alcohol do you consume in a week? }\end{array}$} & No responses & 207 & 76.2 \\
\hline & $30 \mathrm{ml}$ & 14 & 6 \\
\hline & $60 \mathrm{ml}$ & 8 & 3.4 \\
\hline & $90 \mathrm{ml}$ & 7 & 3.4 \\
\hline & $>90 \mathrm{ml}$ & 29 & 10.9 \\
\hline & Total & 265 & 100 \\
\hline \multirow{6}{*}{$\begin{array}{l}\text { 9. If you consume recreational drugs mention in which } \\
\text { form do you consume? }\end{array}$} & No responses & 259 & 69.1 \\
\hline & Marijuana & 1 & 0.4 \\
\hline & Lysergic acid diethylamide(LSD) & 2 & 0.8 \\
\hline & Powder & 1 & 0.4 \\
\hline & Smoke (weed) & 2 & 0.8 \\
\hline & Total & 265 & 100 \\
\hline \multirow{4}{*}{$\begin{array}{l}\text { 10. How much time in a day do you engage in Physical } \\
\text { activity? }\end{array}$} & StrenousPhysical activity & 63 & 23.8 \\
\hline & Moderate Physical activity & 65 & 24.5 \\
\hline & Mild Physical activity & 94 & 35.5 \\
\hline & No Physical activity & 43 & 16.3 \\
\hline
\end{tabular}


Renu Pattanshetty, Siddhi Gotecha, Harshitha Hugar. Perception and Knowledge Regarding Role of Physiotherapy in Oral/Mouth Cancer Survivors amongst Non Medical Professionals: An E-Survey.

Table 2: Table no. 2 Participants knowledge regarding oral cancer (A), their causes (B), problems faced by oral cancer survivors (C) treatment options in oral cancer (D)

\begin{tabular}{|c|c|c|c|}
\hline $2 \mathrm{~A}$ & Responses & Frequency & Percentage \\
\hline \multirow{3}{*}{ 1. Have you heard about Oral/Mouth Cancer? } & Yes & 246 & 92.8 \\
\hline & No & 19 & 7.2 \\
\hline & Total & 265 & 100 \\
\hline \multirow{3}{*}{$\begin{array}{l}\text { 2. Do you know Oral/Mouth Cancer is the } 2^{\text {nd }} \\
\text { highest cause of deaths in India? }\end{array}$} & Yes & 145 & 54.7 \\
\hline & No & 120 & 45.3 \\
\hline & Total & 265 & 100 \\
\hline \multirow{5}{*}{$\begin{array}{l}\text { 3. According to you, which is the most } \\
\text { commonest age group which can be affected by } \\
\text { Oral/Mouth Cancer? }\end{array}$} & $10-19$ years & 6 & 2.3 \\
\hline & 20-39 years & 96 & 36.2 \\
\hline & $40-60$ years & 142 & 53.6 \\
\hline & 60 years and above & 21 & 7.9 \\
\hline & Total & 265 & 100 \\
\hline \multirow{3}{*}{$\begin{array}{l}\text { 4. Do you know males in India suffer from } \\
\text { Oral/Mouth Cancer more than females? }\end{array}$} & Yes & 187 & 70.6 \\
\hline & No & 78 & 29.4 \\
\hline & Total & 265 & 100 \\
\hline \multirow{3}{*}{ 5. Do you think Oral/Mouth Cancer is contagious? } & Yes & 93 & 35.1 \\
\hline & No & 172 & 64.9 \\
\hline & Total & 265 & 100 \\
\hline & Yes & 106 & 40 \\
\hline 1. Having previous history of any Cancers? & No & 159 & 60 \\
\hline & Total & 265 & 100 \\
\hline & Yes & 138 & 52.1 \\
\hline 2.Consumption of alcohol? & No & 127 & 47.9 \\
\hline & Total & 265 & 100 \\
\hline & total & 265 & 100 \\
\hline 3. Use of tobacco in any form? & Yes & 137 & 51.7 \\
\hline & No & 128 & 48.3 \\
\hline & Yes & 97 & 36.6 \\
\hline 4. Poor oral hygiene? & No & 168 & 63.4 \\
\hline & Total & 265 & 100 \\
\hline & Yes & 110 & 41.5 \\
\hline 5. Bleeding from mouth/gums? & No & 155 & 58.5 \\
\hline & Total & 265 & 100 \\
\hline & Yes & 92 & 34.7 \\
\hline 6. Exposure to Human Papilloma Virus (HPV)? & No & 173 & 65.3 \\
\hline & Total & 265 & 100 \\
\hline $2 \mathrm{C}$ & Yes & 145 & 54.7 \\
\hline 1. A long standing non healing ulcer in mouth? & No & 120 & 45.3 \\
\hline 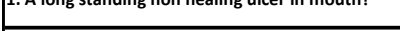 & Total & 265 & 100 \\
\hline & Yes & 130 & 49.1 \\
\hline 2. Boil or infection in mouth? & No & 135 & 50.9 \\
\hline & Total & 265 & 100 \\
\hline & Yes & 143 & 54 \\
\hline 3. Lump in neck/throat/behind the ear? & No & 122 & 46 \\
\hline & Total & 265 & 100 \\
\hline & Yes & 140 & 52.8 \\
\hline 4. Unusual bleeding in mouth/gums? & No & 125 & 47.2 \\
\hline & Total & 265 & 100 \\
\hline & Yes & 147 & 55.5 \\
\hline 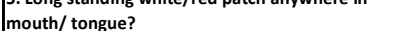 & No & 118 & 44.4 \\
\hline & Total & 265 & 100 \\
\hline & Yes & 153 & 57.7 \\
\hline 6. Difficulty in swallowing, chewing or biting? & No & 112 & 42.3 \\
\hline & Total & 265 & 100 \\
\hline & Yes & 151 & 57 \\
\hline tumor/after surgery? & No & 114 & 43 \\
\hline & Total & 265 & 100 \\
\hline & Yes & 154 & 58.1 \\
\hline 8. Difficulty in talking after surgery? & No & 111 & 41.9 \\
\hline & Total & 265 & 100 \\
\hline & Yes & 133 & 50.2 \\
\hline 9. Dryness in mouth after surgery? & No & 132 & 49.8 \\
\hline & Total & 265 & 100 \\
\hline & Yes & 139 & 52.5 \\
\hline 10. Chronic pain and weakness/fatigue? & No & 126 & 47.5 \\
\hline & Total & 265 & 100 \\
\hline $2 \mathrm{D}$ & Yes & 244 & 92.1 \\
\hline 1. According to you, can Oral/Mouth Cancer be & No & 21 & 7.9 \\
\hline treated? & Total & 265 & 100 \\
\hline & Medical therapy & 145 & 54.7 \\
\hline & Surgery & 83 & 31.3 \\
\hline $\begin{array}{l}\text { 2. Which of the following you teee is the best } \\
\text { treatment for Oral/Mouth Cancer? }\end{array}$ & Physiotherapy & 28 & 10.6 \\
\hline & Others & 9 & 3.4 \\
\hline & Total & 265 & 100 \\
\hline & Yes & 233 & 87.9 \\
\hline 3. Have you ever heard of Physiotherapy? & No & 32 & 12.1 \\
\hline & Total & 265 & 100 \\
\hline & Yes & 101 & 38.1 \\
\hline $\begin{array}{l}\text { any of your ailments/diseases/problems? } \\
\text { anseses }\end{array}$ & No & 164 & 61.9 \\
\hline & Total & 265 & 100 \\
\hline & No responses & 111 & 41.9 \\
\hline 5. If yes, did you find any relief? & Yes & 103 & 38.9 \\
\hline & No & 103 & 19.2 \\
\hline & Total & 265 & 100 \\
\hline
\end{tabular}


Table 3: Importance of physiotherapy in oral cancer (A), knowledge regarding physiotherapy treatment for problems faced by oral cancer survivors (B) \& psycho-social impact on oral cancer survivors (C)

\begin{tabular}{|c|c|c|c|}
\hline \multirow{3}{*}{$\begin{array}{l}\text { 3A } \\
\text { 1. Do you know that physiotherapy is effective in treating } \\
\text { oral/mouth cancer? }\end{array}$} & Yes & 100 & 37.7 \\
\hline & No & 165 & 62.3 \\
\hline & Total & 265 & 100 \\
\hline \multirow{3}{*}{$\begin{array}{l}\text { 2. According to you can giving advice on lifestyle } \\
\text { modification like quitting of smoking/ chewing tobacco } \\
\text { reduces the occurrence of oral/mouth cancer? }\end{array}$} & Yes & 198 & 74.7 \\
\hline & No & 67 & 25.3 \\
\hline & Total & 265 & 100 \\
\hline \multirow{3}{*}{$\begin{array}{l}\text { 3. Do you think physiotherapy helps in palliative care or } \\
\text { terminal(last) stages of oral/mouth cancer? }\end{array}$} & Yes & 156 & 58.9 \\
\hline & No & 109 & 41.1 \\
\hline & Total & 265 & 1000 \\
\hline \multirow{3}{*}{$\begin{array}{l}\text { 4. Do you know physiotherapy can help in increase quality } \\
\text { of life of patients suffering from oral/mouth cancer? }\end{array}$} & Yes & 167 & 63 \\
\hline & No & 98 & 37 \\
\hline & Total & 265 & 100 \\
\hline \multirow{3}{*}{$\begin{array}{l}\text { 3B } \\
\text { 1. Difficulty in mouth opening is managed by using special } \\
\text { equipment and jaw exercises }\end{array}$} & Yes & 207 & 71 \\
\hline & No & 58 & 28 \\
\hline & Total & 265 & 100 \\
\hline \multirow{3}{*}{$\begin{array}{l}\text { 2. Difficulty in talking (communication) is managed by } \\
\text { swallowing exercises }\end{array}$} & Yes & 189 & 71.3 \\
\hline & No & 76 & 28.7 \\
\hline & Total & 265 & 100 \\
\hline \multirow{3}{*}{$\begin{array}{l}\text { 3. Pain around mouth or from site of removal of } \\
\text { tumor/mass is managed using special techniques by } \\
\text { physiotherapists }\end{array}$} & Yes & 208 & 78.5 \\
\hline & No & 57 & 21.5 \\
\hline & Total & 265 & 100 \\
\hline \multirow{3}{*}{$\begin{array}{l}\text { 4.Pain which is referred to other areas ( e.g. Neck, } \\
\text { shoulder, hand) is managed by using special } \\
\text { techniques performed by physiotherapists }\end{array}$} & Yes & 213 & 80.4 \\
\hline & No & 52 & 19.6 \\
\hline & Total & 265 & 100 \\
\hline \multirow{3}{*}{$\begin{array}{l}\text { 5.Swelling (lymph edema) present in the arms and } \\
\text { hands that is managed by therapeutic massage }\end{array}$} & Yes & 207 & 78.1 \\
\hline & No & 52 & 21.9 \\
\hline & Total & 265 & 100 \\
\hline \multirow{3}{*}{$\begin{array}{l}\text { 6.Breathing difficulty (if any) that is dealt by breathing } \\
\text { exercises like pranayama }\end{array}$} & Yes & 208 & 78.5 \\
\hline & No & 57 & 21.5 \\
\hline & Total & 265 & 100 \\
\hline \multirow{3}{*}{$\begin{array}{l}\text { 7.Strengthening the week muscles of face/neck and } \\
\text { shoulder with exercises and equipments }\end{array}$} & Yes & 208 & 78.5 \\
\hline & No & 57 & 21.5 \\
\hline & Total & 265 & 100 \\
\hline \multirow{3}{*}{$\begin{array}{l}\text { 8.Improve the decreased joint movement neck shoulders } \\
\text { by performing specific exercises }\end{array}$} & Yes & 216 & 81.5 \\
\hline & No & 49 & 18.5 \\
\hline & Total & 265 & 100 \\
\hline \multirow{3}{*}{$\begin{array}{l}\text { 9. Fatigue/ weakness and pain is managed by } \\
\text { relaxation exercise }\end{array}$} & Yes & 209 & 78.9 \\
\hline & No & 56 & 21.1 \\
\hline & Total & 265 & 100 \\
\hline \multirow{3}{*}{$\begin{array}{l}\text { 3C } \\
\text { 1. According to you, do patient suffering from oral/mouth } \\
\text { cancer have low self-esteem }\end{array}$} & Yes & 205 & 77.4 \\
\hline & No & 60 & 22.6 \\
\hline & Total & 265 & 100 \\
\hline & Yes & 216 & 81.5 \\
\hline 2. Do you think patients suffering from oral/mouth cancer & No & 49 & 18.5 \\
\hline & Total & 265 & 100 \\
\hline & Yes & 245 & 92.5 \\
\hline 3. Do patients with cancer fear about death? & No & 20 & 7.5 \\
\hline & Total & 265 & 100 \\
\hline & Yes & 210 & 79.2 \\
\hline 4. Have you noticed that people with oral/mouth cancer & No & 55 & 20.8 \\
\hline & Total & 265 & 100 \\
\hline & Yes & 184 & 69.4 \\
\hline 5. Do you think oral/mouth cancer is a social stigma? & No & 81 & 30.6 \\
\hline & Total & 265 & 100 \\
\hline & Yes & 168 & 63.4 \\
\hline $\begin{array}{l}\text { 6. Have you noticed that oral/mouth cancer patients are } \\
\text { not acceptable by the society? }\end{array}$ & No & 97 & 36.6 \\
\hline & Total & 265 & 100 \\
\hline & Yes & 216 & 82.3 \\
\hline 7. Do you think poverty affects patients with oral/mouth & No & 47 & 17.7 \\
\hline & Total & 265 & 100 \\
\hline & Yes & 210 & 79.2 \\
\hline $\begin{array}{l}\text { develop an antisocial behavior? } \\
\text { develal/moutn cancer }\end{array}$ & No & 55 & 20.8 \\
\hline & Total & 265 & 100 \\
\hline & Yes & 182 & 68.7 \\
\hline $\begin{array}{l}\text { 9. According to you, can patients with oral/mouth cancer } \\
\text { effectively work in normal environment? }\end{array}$ & No & 83 & 31.3 \\
\hline & Total & 265 & 100 \\
\hline
\end{tabular}


(Table 2A) It was observed that the respondents ( $n=138$ and $n=137)$ ) had knowledge regarding consumption of alcohol and tobacco as a cause of oral cancer. (Table 2B) 154 respondents were familiar that oral cancer surgeries would lead to difficulty in talking, swallowing, chewing, biting and opening mouth. Respondents were aware that long standing white or red patch anywhere in the mouth or tongue $(n=147)$ and/or a long standing non healing ulcer in mouth $(n=145)$. (Table $2 C)$ Participants knowledge regarding treatment of oral/ mouth cancer was found to be adequate as most of them were aware that oral cancer can be treated $(n=244)$. According to respondents felt that best form of treatment for oral cancer was medical therapy $(n=145)$ Most of the respondents knew about physiotherapy as a treatment option $(n=233)$. (Table 2D) According to $n=167$ respondents, physiotherapy is helpful in improving quality of life in oral cancer survivors. (Table 3A) Most respondents had knowledge regarding decreased joint movement in neck/shoulder can be is managed by performing specific exercises $(n=216)$. Respondents $(n=213)$ were aware of referred pain that could be managed using special equipment. Respondents were also aware that fatigue/weakness could be managed by relaxation exercises, difficulty in mouth opening by using special equipment and jaw exercises (Table 3B) Respondents knowledge regarding psycho-social impact on cancer survivors was good as most of them agreed that patients with oral cancer fear about death $(n=245)$. Most respondents agreed that cancer survivors are depressed and disease is a social stigma. (Table $3 \mathrm{C}$ ).

\section{DISCUSSION}

It's known that knowledge of physiotherapy utilization as a treatment option in the field of musculoskeletal, neurosciences, and sports is adequate, whereas in fields like plastic surgery, oncology, gynecology \& obstetrics is quite poor [5]. Therefore, the present study recruited non medical professionals to assess the perception and knowledge regarding role of physiotherapy in oral/mouth cancer survivors, and the major results of the present study shows that maximum non medical professionals had knowledge regarding integrating physiotherapy services in treating problems faced by oral cancer survivors, since there was no data available.

The results of this study demonstrated that the $92.8 \%$ of the respondents who were non medical professionals had fair knowledge regarding oral/mouth cancer and over $60 \%$ of the respondents were aware that oral cancer is not contagious. A study by Maweri et al was conducted which stated that $71.5 \% \quad(n=543)$ of the respondents had heard about oral cancers and $37.8 \%$ were aware that oral cancer is not contagious.

There was general lack of knowledge observed among general population [6].

Findings from the present study identified that the respondent $\mathrm{s}$ had knowledge about alcohol (52.1) and tobacco (51.7\%) consumption as a major risk factor for oral cancer. In a study conducted by the authors Devadiga A \& Prasad K among dental students suggested that only $69.8 \%$ and $37.8 \%$ respondents were able to identify tobacco and alcohol respectively as risk factors for oral cancer. ${ }^{7}$

According to the results of the current study $63.4 \%$ of respondents did not know about poor oral hygiene as a risk factor for Oral cancer. However in a study conducted by Gupta B et al found that poor oral hygiene is strongly associated with increased risk of oral cancer along with chewing tobacco. Missing more than five teeth was considered a marker of increased risk of oral cancer; however this question was not a part of our self designed questionnaire [8]. Human papilloma virus (HPV) is known to be one of the commonest cause of oral cancer next to tobacco, alcohol and oral hygiene [9].

In present study, only $34.7 \%$ non medical professionals were aware that human papilloma virus (HPV) is a cause for oral cancer; whereas it is known that oropharyngeal cancer is strongly associated with 
serologic measures of exposure to HPV-16 and with presence of oral HPV infections. Meurman J [9] found that Candida albicans is a commonly isolated yeast in the oral cavity that is seen particularly among medically compromised patients. This may also be a cause for oral cancer since Candida in general is more prevalent on carcinoma lesions than on healthy mouth mucosa. Also a specific oral bacteria have shown a role in carcinogenesis along with poor oral hygiene increases the risk of oral cancer [10].

The results drawn from this study regarding the problems faced by oral cancer patients were satisfactory as more than half of the respondents knew that unusual bleeding from gums/mouth ( $n=52.8 \%)$, long standing white/red patch on tongue ( $n=55.5 \%)$, difficulty in swallowing, chewing, biting $(n=57.7)$ and dryness in mouth $(n=50.2)$ are the problems commonly faced by oral cancer survivors. Babiker $\mathrm{T}$ et al reported that out of 500 participants more than half of the respondents had satisfactory knowledge in regards to problems such as dry mouth, bleeding from gums, recurrent tonsillitis, burning sensations numbness, difficulty in swallowing, teeth loosing, white/red patches and swelling faced by the oral cancer survivor [11].

The results of the above mentioned study and the present study were consistent.

Most respondents in this study had adequate knowledge regarding treatment options for oral cancer, since $54.7 \%$ participants choose medical intervention as the first line of treatment for Oral cancer followed by surgery (31.3\%) and then later followed by physiotherapy (10.6\%). A study by Muthu $G$ suggested that $66 \%$ of respondents were aware of treatment options in oral cancer being Medical therapy, Surgery \& Chemotherapy, the respondents were given a questionnaire with 25 structured questions obtain the information [12]. 87.9\% respondents in the present study were aware about the term physiotherapy. $38.1 \%$ $(n=101)$ participants had taken physiotherapy treatment for their ailments/problems out of which $29.4 \%(n=78)$ felt relief post treatment. These findings were correlated with study conducted Doshi D et al where in 153 participants among the general population were surveyed and the results obtained were on the same lines with the current study; the study concluded that there need to create more awareness about the specialties in the field of physiotherapy [5].

Respondents knowledge regarding importance of physiotherapy in oral cancer was seen to be moderate. Respondents were known that physiotherapy is effective in treating oral cancer survivors for the functional limitations post surgery and that physiotherapy can help in palliative care or terminal stages of oral cancer also helps improve cancer related fatigue. Similar findings were seen in study conducted in 2010 which has documented that after giving intervention for period of 2 weeks (3 sessions per week) and each lasting for 30 minutes, programme included Active exercises of upper \& lower limbs, selected techniques of myofacial release, proprioceptive neuromuscular facilitation. The analysis of the results demonstrated a significant decrease in fatigue scores (BFI) [13]

In the present study, most of the participants had considerable knowledge regarding importance of physiotherapy in treating the problems faced by oral cancer survivors such as difficulty in mouth opening, difficulty in talking, swelling (lymphedema), breathing difficulty, decreased ROM of neck \& shoulder. A study supporting the underlying study was conducted in the year 2020 which concluded that a structured exercise protocol, manual lymphatic drainage, compression bandaging and TENS are useful in alleviating the symptoms experienced by oral cancer survivors. Massage therapy including effleurage, light stroking, petrissage, tapotment along with vibration was given for 30-45 minutes per session twice weekly and had considerable results in survivors. Deep breathing exercises, muscle relaxation training showed significant difference in participants. 2-3 layers of short stretch bandage compression 
applied over edematous limb and it showed improvement in limb volumes of the subjects This review based study throws light on the scope of physiotherapy in hospice care and its benefits in patients with advanced cancer [14].

Psychological status is one of the major components of Quality of life. In the current study participants knowledge regarding psychosocial impact on oral cancer survivors was relatively higher as $68.7 \%$ participants agreed that patients with oral cancer cannot work effectively in normal environment. Rasmussen $D$ et al conducted a study at the cancer rehabilitation centre by interviewing total of 23 participants twice. The study concluded that cancer survivors are unable to work efficiently, they lose a part of their identity; they lose the personal challenge and satisfaction related to work. Respondents in the study agreed that oral cancer patients are depressed and fear about death [15].

A meta-analysis regarding the Surveillance, Epidemiology, and End Results 18-registry database was queried for the top 20 cancer sites in the database, including HNC suggested suicide as a cause of death in patients with HNC although survival rates in cancer have improved due to improved cancer treatments. However, the risk of death by suicide remains a problem for cancer survivors, particularly those with HNC [16].

However, suicide as reason for death was not included in questionnaire and may be included for future studies.

\section{CONCLUSION}

It was observed that there is sufficient knowledge among non medical professionals regarding oral cancer and physiotherapy treatment in oral cancer survivors. However, there is dire need to take measures to assess and improve awareness regarding physiotherapy as treatment option in cancer to improve the quality of life of oral cancer survivors including in rural population.

\section{ACKNOWLEDGEMENTS}

Special thanks to all non medical professionals who participated in the study for giving their valuable time in mailing the responses. The authors would also like to thank Dr. Prasad Daddikar, Belgaum, Karnataka, for his time and efforts for our data analysis.

Ethical approval: The study was approved by the Institutional Ethical Committee on $6^{\text {th }}$ November 2020.

\section{Conflicts of interest: None}

\section{REFERENCES}

[1]. Guru K, Supe S, Manoor U. A comprehensive review of head and neck cancer rehabilitation: Physical therapy perspectives. Indian Journal of Palliative Care. 2012;18(2):87.

[2]. Kulkarni M. Head and Neck Cancer Burden in India. International Journal of Head and Neck Surgery. 2013;4(1):29-35.

[3]. Byakodi R, Byakodi S, Hiremath S, Byakodi J, Adaki S, Marathe $\mathrm{K}$ et al. Oral Cancer in India: An Epidemiologic and Clinical Review. Journal of Community Health. 2011;37(2):316-319

[4]. Stuiver M, Stout N, Dennett A, Speksnijder C, Campbell K. An international perspective on integrating physiotherapists in oncology care. Journal of Physiotherapy. 2019;65(4):186-188.

[5]. Doshi D, Jiandani M, Gadgil R, Shetty N. Physiotherapy Awareness in Medical and Non Medical Professionals: A Social Media Survey.International Journal of Physiotherapy and Research. 2017;5(2):1971-197

[6]. Al-Maweri S, Addas A, Tarakji B, Abbas A, AlShamiri $H$, Alaizari $N$ et al. Public Awareness and Knowledge of Oral Cancer in Yemen. Asian Pacific Journal of Cancer Prevention. 2015;15(24):10861-10865.

[7]. Devadiga A, Prasad K. Knowledge about oral cancer in adults attending a Dental Hospital in India. Asian Pacific Journal of Cancer Prevention,. 2010;vol 11.

[8]. Gupta B, Bray F, Kumar N, Johnson N. Associations between oral hygiene habits, diet, tobacco and alcohol and risk of oral cancer: A case-control study from India. Cancer Epidemiology. 2017;51:7-14

[9]. Human Papillomavirus and Oropharyngeal Cancer. New England Journal of Medicine. 2007;357(11):1156-1158.

[10]. Meurman J. Infectious and dietary risk factors of oral cancer. Oral Oncology. 2010;46(6):411-413.

[11]. Babiker T, Osman K, Mohamed S, Mohamed M, Almahdi H. Oral Cancer Awareness Among Dental Patients in Omdurman, Sudan: a cross-sectional Study. BMC Oral Health. 2017;17(1): 
[12]. Muthu G. Awareness of Oral Cancer among a Hospital based Out-Patient Population- A Questionnaire Based Study. Journal of Pharmaceutical Sciences and Research. 2016;8(7).

[13]. Pyszora A, Budzyñski J, Wójcik A, Prokop A, Krajnik $M$. Physiotherapy programme reduces fatigue in patients with advanced cancer receiving palliative care: randomized controlled trial. Supportive Care in Cancer. 2017;25(9):2899-2908.

[14]. Vira P, Samuel S, Amaravadi S, Saxena P, Rai PV S, Kurian J et al. Role of Physiotherapy in Hospice Care of Patients with Advanced Cancer: A Systematic Review. American Journal of Hospice and Palliative Medicine ${ }^{\circledR}$. 2020;:104990912095116.
[15]. Rasmussen D, Elverdam B. The meaning of work and working life after cancer: an interview study. Psycho-Oncology. 2008;17(12):1232-1238.

[16]. Osazuwa Peters N, Simpson M, Zhao L, Boakye E, Olomukoro S, Deshields T et al. Suicide risk among cancer survivors: Head and neck versus other cancers. 2018;124(20):4072-4079.

How to cite this article:

Renu Pattanshetty, Siddhi Gotecha, Harshitha Hugar. Perception and Knowledge Regarding Role of Physiotherapy in Oral/Mouth Cancer Survivors amongst Non Medical Professionals: An E-Survey. Int J Physiother Res 2021;9(3):3834-3842. DOI: 10.16965/ijpr.2021.122 